\title{
Analysis of Organizational Culture in Efforts to Improve Audit Opinion (A Case Study of Majene Regency Government)
}

\author{
Nurhidayah $^{1}$, Indayani B ${ }^{2}$ \\ \{nurhidayah@unsulbar.ac.id, Indayani@unsulbar.ac.id\}
}

Faculty of Economi, Sulawesi Barat University, Jln. Prof Baharuddin Lopa, SH Lutang

Majene Sulawesi Barat, Indonesia ${ }^{1,2}$

\begin{abstract}
This research was conducted with the aim of examining the effect of organizational culture indicators, namely discipline, openness, mutual respect and cooperation on audit opinion. This research focused on a quantitative method with the binary logistic regression analysis. The population in this research were all employees of the reporting division and the organizational division of the Majene Regency Government, the samples of this research were 60 samples obtained by using random sampling technique. The results showed that of the four dependent variables, the variable that significantly affects the achievement of audit opinion is the variable of cooperation, and the simultaneous test results showed that the four variables simultaneously had a significant effect on audit opinion.
\end{abstract}

Keywords: Discipline, Openness, Mutual Respect, Cooperation, Audit Opinion.

\section{Introduction}

An unqualified audit opinion is the most desirable opinion by the auditee in an examination of financial statements. Unqualified means that the auditee has presented financial records and statements of a company appropriately and fairly and in accordance with the relevant standards and is free from material misstatement. This opinion is then commonly referred to as an unqualified opinion. According to IAPI (2013), the unqualified opinion indicates that the financial statements have been fairly presented, in all material respects, the financial position, results of operations and cash flows of the entity are in conformity with generally accepted accounting principles, while the standard of an unqualified audit opinion is issued when all statements are included in the financial statements, the three general standards have been followed in all respects on the engagement, sufficient appropriate evidence has been accumulated and the three standards of field work have been met, the financial statements have been presented in accordance with GAAP (Greneral Accepted Accounting Principles) and there are no circumstances requiring the addition of an explanatory paragraph or modification of the wording of the report [1].

In Regional Governments, external audits are conducted by the Audit Board of Indonesia (BPK). The form of regional government accountability is made in the form of Regional Government Financial Statements (LKPD) in accordance with the Government Accounting 
Standards Statement (PSAP). BPK has the right and discretion in the audit process with three stages, starting with planning the audit, conducting the audit to reporting the audit results. At the final reporting stage, an Audit Result Report (LHP) is given to the auditee, in this case the regional government, and this is where the opinions given are contained.

Research conducted by (Rante, Salle, and merlissa n.d.) found that the unqualified audit opinion was not reached due to non-compliance with the legislation and the implementation of the SPI was not optimal and recommendations from the BPK were not followed up [2]. Furthermore, the research conducted by Milal (2012) found that the success in increasing the role of the Government Internal Supervisory Apparatus (APIP) as Internal Supervisor as well as a consultant in the preparation of Financial Statements of Ministries and Institutions (LKKL) supports the process of achieving the unqualified audit opinión [3]. Research on the determinants of achievement and barriers in obtaining an unqualified audit opinion has been widely carried out, but research that links audit opinion to organizational work culture is still not common, therefore, the present research is conducted as a research development on audit opinion from a slightly different point of view. Organizational culture is the values that are applied in an institution or organization in an effort to achieve the vision and mission of an organization.

Consciously or not, a work culture will be laid as the foundation for the organization to be established, while the application will run and adapt to the times. Organizational culture will provide stability to an organization as it has significant influence on the achievement of an organization by developing strategies carried out by the organization. Rizkya El Fitria Ali, Djamhur (2011) stated that organizational culture has a major influence on a company's ability to change its strategic direction [4]. A strong corporate culture tends to resist change because of the desire to maintain a stable pattern of behavior. An optimal culture is a culture that can properly support the mission and strategy of the company, so that the organizational culture must follow the strategy set by the company. Organizational work culture is a form of individual and group efforts in achieving the organization goal or vision and mission set by the organization. (Kementerian Agama 2010) in Al-Qur'an Surah Ar-ra'ad:11 Allah says that Allah will not change the condition of a people, unless there is a change of what is in themselves [5]. From this verse, we can understand that one of the things we can change to achieve a good goal is a good culture.

Majene Regency Government has obtained an audit opinion with an unqualified predicate for 5 consecutive years, namely since the fiscal years 2015, 2016, 2017, and 2018. And the Majene Regency Government has once again achieved an unqualified audit opinion in the fiscal year 2019 (Mejenekab.go.id n.d.) [6]. Based on this phenomenon, researchers are interested in conducting research on organizational work culture that is applied in an effort to achieve and maintain the unqualified performance of an audit opinion obtained by the Majene Regency Government. Referring to this background description, the researchers are interested in conducting research on "Analysis of Organizational Culture in Efforts to Improve Audit Opinion (A Case Study of Majene Regency Government, West Sulawesi). 


\section{Method}

\subsection{Types of Research}

This research focused on the quantitative method used to examine the effect between the dependent variable and the independent variable of this research. Quantitative research is a type of research conducted with the aim of obtaining a mathematical pattern or model as evidence of an implementation of a research.

Sugiyono (2018) stated that quantitative method of research is a research method based on positivism philosophy, used to examine a predetermined population and sample using sampling techniques, and data collection using research instruments [7].

\subsection{Types and Sources of Data}

The type of data used in this research was primary data. Primary data is a type of data that is collected by researchers from first-hand sources Umar (2012). In this research, the research instruments were distributed to the respondents, namely the employees of the Majene Regency Government [8].

\subsection{Data Collection Method}

The data collection method in this research was carried out through observation, interviews, distributing questionnaires and documentation. The process was carried out by collecting, coding, scoring and tabulating the data.

\subsection{Population and Sample}

The population in this research were all employees of the reporting division and the organizational division of the Majene Regency Government, West Sulawesi. The research sample was the result of the sampling technique conducted by using random sampling, namely simple random sampling, where each element or member of the population has an equal chance of being selected as the sample of this research.

\subsection{Operational Definition and Variable Measurement}

1. Dependent Variable (X)

The following are the variables and their measurements contained in this research:

a. Discipline (Variable X1)

Discipline variable in this research is an indicator of the organizational culture applied by the Majene Regency Government which shows that employees have compliance with regulations including laws, standard operating procedures and time in carrying out tasks or jobs.

b. Openness (Variable X2)

Openness variable in this research is an indicator of the organizational culture applied by the Majene Regency Government which shows clearness and the state of being 
open, honest, and straightforward in all areas, including in reporting, or compilation of accountability. Openness is usually referred to as transparency.

c. Mutual Respect (Variable X3)

Mutual respect variable in this research is also an indicator of the organizational culture applied by the Majene Regency Government. Mutual respect shows an attitude of tolerance horizontally or vertically, individually or in a group.

d. Cooperation (Variable X4)

Cooperation variable in this research is also an indicator of the organizational culture applied by the Majene Regency Government, which is defined as a form of cohesiveness in team work between employees, and between employees and managers.

The four dependent variables were measured by giving a value to each questionnaire question instrument which was responded to by the respondents who were the samples in this research, while the weight of the assessment is as follows:

Table 1. The Weight of the Questionnaire Assessment

\begin{tabular}{|c|c|c|}
\hline Answer & Positive Questions & Negative Questions \\
\hline Always & 5 & 1 \\
\hline Often & 4 & 2 \\
\hline Sometimes & 3 & 3 \\
\hline Rarely & 2 & 4 \\
\hline Never & 1 & 5 \\
\hline
\end{tabular}

2. Independent Variable (Y)

The independent variable in this research is the audit opinion, which is the achievement of the audit results of the Majene Regency Government Financial Report from an external auditor, in this case the Audit Board of Indonesia (BPK RI), Representative of West Sulawesi. This variable was measured by using the measurement of dummy variables where an unqualified opinion obtained is given a value of 1 and an adverse opinion is given a value of 0 .

Rizki (2014) explained that dummy variables are used to test independent variables whose size cannot be scaled or categorized. In a regression, we can include qualitative variables [9]. If the independent variable is categorized, the regression model is stated by giving the code 0 (zero) or 1 (one).

\subsection{Data Analysis Method}

This research used binary logistic regression analysis, through the following analysis stages:

1. Data Quality Test

a. Validity Test, the validity test is used to measure how valid a questionnaire is. A questionnaire is said to be valid if the questions can reveal something which is supposed to be measured by the questionnaire [10]. Validity test is done through Pearson correlation, if the significance value is $5 \%$ and $\mathrm{r}$ count $>\mathrm{r}$ table, then the instrument is declared valid. 
b. Reliability Test, the reliability test is carried out to measure the questionnaire which is used as an indicator of a variable, a questionnaire is called reliable if answer to the questionnaire is consistent or stable over time [10]. Testing is done with coach alpha statistics, it is said to be reliable if the coach alpha (a) value $>0.6$.

2. Binary Logistic Regression Analysis

This research used binary logistic regression analysis, because the independent variable is a categorical variable or dummy variable. According to Ghozali (2016), logistic regression is a special form of regression analysis where the independent variables are categorical, continuous or a combination of the two [10]. This logistic regression test is used to determine that the probability of the dependent variable can be predicted through the independent variable. The regression equation model in this research is:

$$
\operatorname{Ln} \frac{\mathrm{WTP}}{1-\mathrm{WTP}}=\mathrm{a}+\beta 1(\mathrm{DI})+\beta 2(\mathrm{TR})+\beta 3(\mathrm{SM})+\beta 4(\mathrm{KS}) €
$$

Where: $\quad \operatorname{Ln} \frac{\text { WTP }}{1-\text { WTP }}$

a
$\beta$
DI
TR
SM
KS
$€$

$$
\begin{aligned}
& =\text { Unqualified Opinion } \\
& =\text { Constant } \\
& =\text { Intercept } \\
& =\text { Discipline } \\
& =\text { Openness } \\
& =\text { Mutual Respect } \\
& =\text { Cooperation } \\
& =\text { Error }
\end{aligned}
$$

The stages in conducting binary logistic regression testing are as follows:

1. Regression Model Feasibility Test

The feasibility test of the regression model on binary logistics can be seen in the output of hosmer and lemeshows, on the basis of decision making, namely paying attention to the chi-square value, if the probability $>0.05$, then the test hypothesis is accepted, on the contrary if the probability $<0.05$, then the test hypothesis is rejected.

2. Whole Model Test

The feasibility test of the whole model can be seen in the omnibus test, if the probability shows less than 0.05 , it is said to be simultaneously influential.

3. Coefficient of Determination Test

The coefficient of determination test is carried out to find out how much the dependent variable can be explained by the independent variable, it can be seen in R Square [10].

4. Multicollinearity Test

Multicollinearity test in binary logistic regression can be tested by looking at the correlation coefficient between independent variables, if the probability of the independent variable is smaller than 0.8 , it means that there are no symptoms of multicollinearity [11]. 


\section{Results}

\subsection{Data Quality Test}

1. Validity test

The results of the validity test showed that the research data can be said to be valid, the Pearson correlation shows that each variable is greater than $r$ table, where the value of $r$ table with $\mathrm{N}=60$ is 0.214 .

Table 2. Correlations

\begin{tabular}{|c|c|c|c|c|}
\hline & & Discipline & Openness & Mutual_Respect \\
\hline \multirow[t]{3}{*}{ Discipline } & Pearson Correlation & 1 & $.821^{* *}$ & $.654^{* *}$ \\
\hline & Sig. (2-tailed) & & .000 & .000 \\
\hline & $\mathrm{N}$ & 60 & 60 & 60 \\
\hline \multirow[t]{3}{*}{ Openness } & Pearson Correlation & $.821^{* *}$ & 1 & $.763^{* *}$ \\
\hline & Sig. (2-tailed) & .000 & & .000 \\
\hline & $\mathrm{N}$ & 60 & 60 & 60 \\
\hline \multirow[t]{3}{*}{ Mutual_Respect } & Pearson Correlation & $.654^{* *}$ & $.763^{* *}$ & 1 \\
\hline & Sig. (2-tailed) & .000 & .000 & \\
\hline & $\mathrm{N}$ & 60 & 60 & 60 \\
\hline \multirow[t]{3}{*}{ Cooperation } & Pearson Correlation & $.648^{* *}$ & $.711^{* *}$ & $.869^{* *}$ \\
\hline & Sig. (2-tailed) & .000 & .000 & .000 \\
\hline & $\mathrm{N}$ & 60 & 60 & 60 \\
\hline \multirow[t]{3}{*}{ BPK_Opinion } & Pearson Correlation & .229 & .233 & .242 \\
\hline & Sig. (2-tailed) & .078 & .074 & .062 \\
\hline & $\mathrm{N}$ & 60 & 60 & 60 \\
\hline
\end{tabular}

2. Reliability Test

The results of the reliability test showed that the research data can be said to be reliable, this can be proven by comparing the coach alpha (a) value which is above 0.6 or $0.870>0.6$.

Table 3. Reliability Statistics

\begin{tabular}{crr}
\hline Cronbach's Alpha & N of Items \\
\hline & .870 & 5 \\
\hline
\end{tabular}

\subsection{Binary Logistic Regression Analysis}

Table 4. Case Processing Summary

\begin{tabular}{llrr}
\hline Unweighted Cases $^{\mathrm{a}}$ & & $\mathrm{N}$ & \multicolumn{2}{c}{ Percent } \\
\hline Selected Cases & Included in Analysis & 60 & 100.0 \\
& Missing Cases & 0 & .0
\end{tabular}




\begin{tabular}{lrrr} 
& Total & 60 & 100.0 \\
Unselected Cases & & 0 & .0 \\
Total & 60 & 100.0 \\
\hline
\end{tabular}

a. If the weight is in effect, see the classification table for the total number of cases.

From the Case Processing Summary table, we can see that this research has $\mathrm{N}$ of 60 , or 60 data entered into the regression.

Table 5. Dependent Variable Encoding

\begin{tabular}{ll}
\hline Original Value & Internal Value \\
\hline NON WTP & 0 \\
WTP & 1 \\
\hline
\end{tabular}

Dependent Variable Encoding table indicates that the dependent variable in this research is a dummy variable or categorical variable, in which the category of unqualified audit opinion is given a code or value of 1 and the category of adverse audit opinion is given a code or value of 0 .

1. Regression Model Feasibility Test

Table 6. Hosmer and Lemeshow Test

\begin{tabular}{llllll}
\hline Step & Chi-square & Df & & Sig. & \\
\hline 1 & 3,925 & & 7 & & .788 \\
\hline
\end{tabular}

Significance value at Hosmer and Lemeshow Test table shows a significance of 0.788 or greater than $0.05 \%$, meaning that the equation obtained has met the requirements for the binary logistic regression test.

2. Whole Model Test

The Omnibus Tests of Model Coefficients table shows a significance of $0.008<0.05$, this means that the dependent variables simultaneously affect the independent variable, which is the audit opinión.

Table 7. Omnibus Tests of Model Coefficients

\begin{tabular}{llrrrr}
\hline & & Chi-square & df & Sig. \\
\hline Step 1 & Step & 13,839 & 4 & .008 \\
& Block & 13,839 & 4 & .008 \\
& Model & 13,839 & 4 & .008 \\
\hline
\end{tabular}

\section{Coefficient of Determination}

Cox \& Snell R Square on the Model Summary table shows a value of 0.206. This means that the independent variable can explain the dependent variable by $20.6 \%$ and the remaining $79.4 \%$ is explained by other variables outside of this research.

Table 8. Model Summary

\begin{tabular}{lrrrr}
\hline & & \multicolumn{2}{c}{ Cox \& Snell R } & \multicolumn{2}{c}{ Nagelkerke R } \\
Step & -2 Log likelihood & Square & Square & \\
\hline 1 & $69,339^{\mathrm{a}}$ & .206 & .275 \\
\hline
\end{tabular}


a. Estimation terminated at iteration number 4 because parameter estimates changed by less than .001 .

The Iteration History table shows that in the regression model before the inclusion of the dependent variables, the constant coefficient shows a value of 0.000 , meaning that in this research, before the inclusion of the dependent variables, namely discipline, openness, mutual respect, and cooperation, the model coeficients $=0$.

Table 9. Iteration History $y^{\mathrm{a}, \mathrm{b}, \mathrm{c}}$

\begin{tabular}{lrrr}
\hline & & \multicolumn{2}{c}{ Coefficients } \\
\cline { 3 - 4 } Iteration & -2 Log likelihood & \multicolumn{2}{c}{ Constant } \\
\hline Step 0 & 1 & 83,178 & .000 \\
\hline
\end{tabular}

a. Constant is included in the model.

b. Initial -2 Log Likelihood: 83,178

c. Estimation terminated at iteration number 1 because parameter estimates changed by less than, 001 .

4. Multicollinearity Test

Multicollinearity test results on the correlation matrix table shows that there is no multicollinearity in this research, this can be proven from the correlation value between the independent variables which is averagely still below 0.8 , it can be seen more clearly in the following table:

Table 10. Correlation Matrix

\begin{tabular}{llrrrrr}
\hline & Constant & Discipline & Openness & Mutual_Respect & \multicolumn{1}{c}{ Cooperation } \\
\hline Step 1 & Constant & 1.000 & -.019 & -.182 & -.029 & -.276 \\
& Discipline & -.019 & 1.000 & -.687 & .046 & -.126 \\
& Openness & -.182 & -.687 & 1.000 & -.327 & -.022 \\
& Mutual_Respect & -.029 & .046 & -.327 & 1.000 & -.728 \\
& Cooperation & -.276 & -.126 & -.022 & -.728 & 1.000 \\
\hline
\end{tabular}

5. Regression Model and Hypothesis Testing

The regression coefficient test shows the results that can be seen in the Variable in the Equation table. The following table shows the test results through the binary logistic regression test with a significance level of 0.05

Table 11. Variables in the Equation

\begin{tabular}{llrrrrrr}
\hline & \multicolumn{1}{c}{ B } & \multicolumn{1}{c}{ S.E. } & Wald & df & \multicolumn{1}{c}{ Sig. } & \multicolumn{1}{c}{$\operatorname{Exp}(\mathrm{B})$} \\
\hline Step $1^{\mathrm{a}}$ & Discipline & .029 & .905 & .001 & 1 & .974 & 1.030 \\
& Openness & .050 & 1.140 & .002 & 1 & .965 & 1.051 \\
& Mutual_Respect & -1.881 & 1.211 & 2.410 & 1 & .121 & .152 \\
& Cooperation & 3.209 & 1.181 & 7.388 & 1 & .007 & 24.751 \\
& Constant & -6.285 & 2.678 & 5.509 & 1 & .019 & .002 \\
\hline
\end{tabular}

a. Variable(s) entered on step 1: Discipline, Openness, Mutual_Respect, Cooperation.

From the results of the binary logistic regression equation test above, the logistic regression model shown is:

$$
\operatorname{Ln} \frac{\mathrm{WTP}}{1-\mathrm{WTP}}=-6.285+0.029(\mathrm{BD})+0.050(\mathrm{BT})-1.881(\mathrm{BSM})+3,209(\mathrm{BK})+€
$$


The interpretation of the formed logistic regression model results shows a constant of 6.285. Which means that if it is not affected by the dependent variable, namely discipline, openness, mutual respect and cooperation, or in other words that if the independent variable is considered zero, then the independent variable, namely audit opinion, does not change or remains at a value of -6.285 .

The regression coefficient value of 0.029 means that when there is an increase in the culture of discipline, then the Majene Regency Government tends to obtain an unqualified opinion with insignificant effect.

The regression coefficient value of 0.050 means that when there is an increase in the culture of openness, then the Majene Regency Government tends to obtain an unqualified opinion with insignificant effect. The regression coefficient value of -1.881 means that when there is an increase in the culture of mutual respect, then the Majene Regency Government tends to obtain an adverse opinion with insignificant effect. The regression coefficient value of 3.209 means that when there is an increase in the culture of cooperation, then the Majene Regency Government tends to obtain an unqualified opinion with significant effect.

\subsection{H1 Discipline has a Significant Effect on Audit Opinion}

The test results of the Discipline variable showed that (B) is at a value of 0.029 with a significance of 0.974 or above the $5 \%$ level, then the results of the H1 hypothesis testing which states that discipline has an effect on audit opinion in the Majene Regency Government is rejected.

\subsection{H2 Openness has a Significant Effect on Audit Opinion}

The test results of the Openness variable showed that $(\mathrm{B})$ is at a value of 0.050 with a significance level of 0.965 or above 0.05 , then the results of the $\mathrm{H} 2$ hypothesis testing which states that the culture of openness has a significant effect on audit opinion in the Majene Regency Government is also rejected.

\subsection{H3 Mutual Respect has a Significant Effect on Audit Opinion}

The test results of the Mutual Respect variable based on the variables in the Equation table showed that (B) is at a value of -1.881 with a significance level of 0.121 and above $5 \%$, then the results of the $\mathrm{H} 3$ hypothesis testing which states that the culture of mutual respect has a significant effect on audit opinion in the Majene Regency Government is also rejected.

\subsection{H4 Cooperation has a Significant Effect on Audit Opinion}

The test results of the Cooperation variable showed a result of 3.209 at the significance level of 0.007 or below the value of 0.05 , then the results of the H4 hypothesis testing which states that cooperation has a significant effect on audit opinion in the Majene Regency Government is accepted.

\subsection{H5 Discipline, Openness, Mutual Respect and Cooperation Have Significant Effects on Audit Opinion}


The significance value in the table of omnibus tests of model coeficients which is a whole or simultaneous test showed a value of 0.008 or is below the significance level of 0.05 , then the results of the $\mathrm{H} 5$ hypothesis testing which states that discipline, openness, mutual respect and cooperation have a significant effect on audit opinion in the Majene Regency Government is accepted.

\section{Discussion}

\subsection{The Effect of Discipline on Audit Opinion}

The culture of discipline in general is a culture that is always applied to every organizational institution, this is also applied to the Majene Regency Government. From the results of logistic regression testing, it can be seen that the culture of discipline had a positive not significantly effect, this means that when the discipline is further improved, it shows that the unqualified audit opinion will tend to be obtained. Based on the results of the interview with the regional government organization of Majene Regency, there was an increase in discipline at the time before the achievement of an unqualified audit opinion, with or after obtaining an unqualified audit opinion, although it is known that because of the current covid19 outbreak, there has been a shift in the habit of discipline and there have been separate regulations in the current situation.

\subsection{The Effect of Openness on Audit Opinion}

Openness or usually better known as transparency is also a culture instilled by the Majene Regency Government. From the results of logistic regression analysis, it is known that the culture of openness had a positive not significantly effect on the achievement of unqualified audit opinions, this means that when the culture of openness is further improved, it shows that the unqualified audit opinion will tend to be obtained by the Majene Regency Government. Transparency here is included in the transparency of reporting which is oriented to the public, so the state of being open, honest, and straightforward is highly required in all areas, including in reporting, especially in the Regional Government Financial Report (LKPD) which is the audit object of the auditors.

\subsection{The Effect of Mutual Respect on Audit Opinion}

The results of the regression analysis showed the insignificant negative direct effect, meaning that when the culture of mutual respect is too high, then an adverse audit opinion is tend to be obtained. In this case, excessive culture of mutual respect can lead to the instability for fairness and ethical strength in a work relationship, resulting in a sense of discomfort which can affect the quality control.

\subsection{The Effect of Cooperation on Audit Opinion}

The results of this research indicated that the culture of cooperation showed a significant positive effect on audit opinion, which means that when the Majene Regency Government implements a more tighter culture of cooperation, the tendency for obtaining unqualified audit 
opinion is greater. The results of this research also found that the cooperation variable had a significant amount of effect. In this case, cooperation is not only horizontal but also vertical, including good coordination, the ability of managers to direct employees, and the ability to encourage one another for better achievement. Mutual cooperation is one form of implementing nationalism and always reminding each other in maintaining stability and occupational health.

\subsection{The Effect of Discipline, Openness, Mutual Respect and Cooperation on Audit Opinion}

The results of this research indicated that if the four variables are combined simultaneously, it will significantly affect the dependent variable, namely audit opinion. This means that these four cultures need to be applied together in an effort to achieve an unqualified audit opinion, not only by applying one of them because they require each other and complete one another. The Majene Regency Government has implemented the cultures of discipline, openness, mutual respect and cooperation in efforts to improve and maintain an unqualified audit opinion.

\section{Conclusion}

The results showed that of the four independent variables, namely discipline, openness, mutual respect and cooperation, the variable that significantly affects the achievement of audit opinion is the variable of cooperation. Nonetheless, the four variables simultaneously had the same effect. The variables of discipline, openness and cooperation had a positive direct effect, while the variable of mutual respect had a negative direct effect. As for the simultaneous testing, the results showed that the four variables had a significant effect. The Majene Regency Government has implemented the cultures of discipline, openness, mutual respect and cooperation in efforts to improve and maintain an unqualified audit opinion.

\section{References}

[1] IAPI: Standar Profesional Akuntan Publik, Jakarta: Salemba Empat, (2013).

[2] Rante, I.Salle, A.and Marlissa, E. R.: Analisis Terhadap Pemberian Opini Laporan Keuangan Pemerintah Daerah Kabupaten Pegunungan Bintang, KEUDA J. Kaji. Ekon. DAN Keuang. Drh., vol. 3, no. 2, (2018).

[3] Milal, A.: Makna Opini Audit WTP Bagi Kementerian/Lembaga (Studi Kasus Pada Kementerian Sosial). Universitas Brawijaya, (2013).

[4] Ali, R. E. F.: Peranan Budaya Organisasi Dalam Meningkatkan Komitmen Pegawai (Studi Kasus Pada Pt. Bank Muamalat Indonesia Cabang Malang), J. Adm. Bisnis, vol. 3, no. 2, (2013).

[5] Departemen Agama, R. I.: Al-Quran Dan Tafsirnya (Edisi Yang Disempurnakan) Jilid IV, Jakarta: PT, Lentera Abadi, (2010).

[6] Majenekab: Kabupaten Majene. https://majenekab.go.id/ (accessed Jul. 07, 2020).

[7] Sugiyono:Metode Penelitian Kuantitatif Kualitatif dan R\&D. Bandung: Penerbit Alfabeta, (2015). 
[8] Umar, H.: Penelitian Kuantitatif (Langkah Demi Langkah), Pelatih. Metodol. Penelit. Kopertis III, (2012).

[9] Pratami, R. R.: Pengaruh Jalur Seleksi Masuk, Lingkungan Keluarga Dan Motivasi Belajar Sebagai Variabel Intervening Terhadap Prestasi Belajar Mahasiswa Jurusan Pendidikan Akuntansi Fakultas Ekonomi Universitas Negeri Semarang Tahun 2014. Universitas Negeri Semarang, (2015).

[10] Ghozali, I.: Aplikasi Analisis Multivariant Dengan Program IBMS SPSS 23 Edisi 8, Univ. Diponegoro. Semarang, (2016).

[11] Kuncoro, M.: Metode Riset Untuk Bisnis \& Ekonomi, Edisi Keempat, Jakarta: Erlangga, (2013). 